\title{
THE EFFECT OF FEEDING METHOD ON BODY WEIGHT GAINS, CONCENTRATIONS OF SELECTED COMPONENTS IN THE BLOOD, AND PEROXIDATION PROCESSES OF CARP, CYPRINUS CARPIO L.
}

\author{
Katarzyna STEPANOWSKA*, Anna SAWICKA \\ Division of Human Nutrition Physiology, Agricultural University of Szczecin, Poland
}
Stepanowska K., Sawicka A. 2006. The effect of feeding method on body weight gains, concentrations of selected components in the blood, and peroxidation processes of carp, Cyprinus carpio L. Acta Ichthyol. Piscat. 36 (1): 25-29.

\begin{abstract}
Background. Fish are the principal source of n-3 and n-6 fatty acids for humans. Traditionally, these fatty acids have been supplied in the form of captured marine and freshwater fishes. Recently, freshwater cultured species have been increasing their share in the fish volume on the market. Therefore it is crucial for fish farmers to rear fish under proper condition and with proper feeding in order to receive good quality fish flesh at harvest. The presently reported study was aimed at determining the effect of diet with the increased level of lipids or carbohydrates on selected blood indices, reduced glutathione content, lipid peroxidation products concentration in the liver, and body weight gains in carp fingerlings reared in post-cooling waters.

Materials and Methods. The experiment was carried out in spring (2004) on 300 carp divided into two feeding groups. Group I was fed high-fat feed, whereas group II high-carbohydrate feed. After 7 weeks, fish blood and livers were collected for further analyses.

Results. Significantly higher body weight gains were found in the fish fed high-fat feed as well as significant increase of haemoglobin $(\mathrm{Hb})$ concentration in the blood of both feeding groups, which was accompanied by the increase of haematocrit $(\mathrm{Ht})$ index. Furthermore, an increase in the concentration of lipid peroxidation products was observed as well as significantly lower content of reduced glutathione (GSH) in the livers of fish examined.

Conclusion. The observed MDA values and reduced glutathione (GSH) concentration in the fish liver may indicate enhanced peroxidation processes in the organisms of the fish from both experimental groups, caused by their intensive feeding with extruded feeds. The peroxidation processes were more intensive in fish fed high-fat feeds.
\end{abstract}

Keywords: fish, carp, Cyprinus carpio, haemoglobin (Hb), haematocrit (Ht), reduced glutathione (GSH), lipid peroxidation products (MDA), breeding, nutrition

\section{INTRODUCTION}

Recent years marked a major shift in human understanding of the role of food products in maintaining their proper health status. A particular interest was focused on the role of foodstuffs on prophylaxis and prevention of so called diseases of civilization such as: obesity, non-insulin-dependant diabetes mellitus, circulatory diseases, and neoplastic diseases. It has been explicitly demonstrated in extensive epidemiological studies that $n-3$ and n-6 fatty acids show remarkable physiological and health-oriented properties (Ziemlański and Budzyńska-Topolowska 1992, Budzyńska-Topolowska and Ziemlański 1993, Kolanowski and Świderski 1997, Ziemlański 1997, Arts et al. 2001,). The excellent source of these acids are fish, either free-living ones, acquired from the sea, or increasingly important cultured ones (Steffens and Wirth 2005). This imposes an obligation on fish-farmers to produce fish of, not only, adequate body weight and gustatory values but also of good condition and having specific customer-demanded nutrients, in this number proper lipid levels, of proper quality.

The presently reported study was aimed at determining the effect of lipid- and carbohydrate-enhanced diets on selected blood parameters, reduced glutathione (GSH) content, lipid peroxidation products (MDA) concentrations in the liver, as well as on body weight gains in carp fry reared intensively in post-cooling waters.

\section{MATERIALS AND METHODS}

The experiment was carried out in spring of 2004 at the Experimental Fisheries Station at Nowe Czarnowo on 300 carp, weighing on average $170 \pm 10 \mathrm{~g}$. The fish were rea-

\footnotetext{
*Correspondence: Dr Katarzyna Stepanowska, Zakład Fizjologii Żywienia Człowieka, Akademia Rolnicza w Szczecinie, ul. Papieża Pawła VI 3 , 71-459 Szczecin, Poland, phone: (+4891) 425-0501, e-mail: greyseal@o2.pl
} 
red in 6 cages of $1.0 \mathrm{~m}^{3}$ production volume each, suspended on self-supporting platforms positioned in the postcooling water discharge canal of the Dolna Odra Power Plant. Stocking material consisted of 50 fish in each cage. The fish were randomly divided into two groups and the differentiation factor was the diet composition. Each group was tested in three repetitions. The experiment lasted for 7 weeks.

The fish were fed different commercial feeds, available at the domestic market, and featuring high levels of lipids or carbohydrates (group I and II, respectively). The detailed composition of the feeds is presented in Table 1.

The fish were fed according to the following schemes.

- The standard diet before the start of the experiment: $45 \mathrm{~g}$ of protein $(=754.2 \mathrm{~kJ}=44.6 \%$ of energy); $20 \mathrm{~g}$ of fat ( $=670.4 \mathrm{~kJ}=39.6 \%$ of energy); $16 \mathrm{~g}$ of carbohydrates ( $=268.2 \mathrm{~kJ}=15.8 \%$ of energy); overall calorific value of the feed $=1692.8 \mathrm{~kJ}$.

- Group I (fed high-fat feed): $45.3 \mathrm{~g}$ of protein $(=729.1 \mathrm{~kJ}$ $=38.9 \%$ of energy); $28.6 \mathrm{~g}$ of fat $(=958.7 \mathrm{~kJ}=51.1 \%$ of energy); $11.7 \mathrm{~g}$ of carbohydrates $(=187.7 \mathrm{~kJ}=10.0 \%$ of energy); overall calorific value of $100 \mathrm{~g}$ of the feed $=1875.5 \mathrm{~kJ}$.

- Group II (feed high-carbohydrate feed): $43.7 \mathrm{~g}$ of protein $(=732.4 \mathrm{~kJ}=44.6 \%$ of energy); $14.7 \mathrm{~g}$ of fat $(=492.7 \mathrm{~kJ}=29.9 \%$ of energy); 24.9 g overall calorific value of the feed $=1642.4 \mathrm{~kJ}$.

The fish were fed daily, every 60 minutes $(0900-1500 \mathrm{~h})$. The feed was thrown manually on the water surface in the cages. The daily feed ration, calculated with relation to fish metabolic body weight (Sadowski 1998), amounted to $2 \%$. In order to control fish body weight and correct feed ration, the weights of all fish were monitored every 7 days.

Blood for analyses was collected from the caudal vessels of 12 carp before starting the experiment and of 12 carp after completing the experiment. The procedure was performed for each feeding group and it was carried out between $0730 \mathrm{~h}$ and $0830 \mathrm{~h}$. The blood for haemoglobin and haematocrit readings was collected on heparin whereas that for protein assessments - on coagulum.

Furthermore, the content of reduced glutathione (GSH) (Ellaman's method) and the concentration of lipid perox- idation products (MDA) (reaction with thiobarbituric acid) were analysed in homogenates of fish livers before the experiment and after its completion. Basic physicochemical indices of the water, such as temperature, oxygen level, and $\mathrm{pH}$, were also recorded during the experiment with the aid of automatic analyzer and subsequently analysed (STATISTICA for Windows). Significance of differences was determined basing on one-factor analysis of variance and LSD test.

The experimental protocol had been approved by the Local Ethical Committee for Animal Research (Szczecin, Poland)

\section{RESULTS}

The physico-chemical indices of post-cooling water during the experiment were as follows:

- mean water temperature: $20.3^{\circ} \mathrm{C}$ (range of $19.3-21.2^{\circ} \mathrm{C}$ )

- mean water oxygen content: $8.4 \mathrm{mg} \mathrm{O}_{2} \cdot \mathrm{L}^{-1}$ (range of 7.3-8.9 $\left.\mathrm{mg} \mathrm{O}_{2} \cdot \mathrm{L}^{-1}\right)$

- mean water $\mathrm{pH}: 8.3$ (range of 8.0-8.6).

It was determined that intensive rearing of carp fingerlings which involved using a diet containing increased level of lipids (group I) or carbohydrates (group II) induced significant changes in levels of the analysed blood parameters, liver content of reduced glutathione (GSH), and liver concentration of lipid peroxidation products (MDA), as well as in body weight gains of the experimental fish (Tables 2, 3, 4).

Intensive body weight gains were stated in the carp of both feeding groups, with those being significantly higher $(P \leq 0.01)$ in the fish fed high-fat feed when compared to carp fed high-carbohydrate feed.

Also the increase of haemoglobin concentration in the blood of fish of both feeding groups was highly significant $(P \leq 0.01)$ when compared to the pre-experiment state.

This was accompanied by an increase in the value of haematocrit, which was highly significant $(P \leq 0.01)$ in the fish of group I, fed high-fat feed and significant $(P \leq$ 0.05 ) in those of group II fed high-carbohydrate feed when compared to the initial state.

On the other hand, no changes were observed in the content of total protein in fish blood, both between the feeding groups and when compared to pre-experiment state.

Table 1

Composition of feed mixes used in fish feeding (according to manufacturer's data)

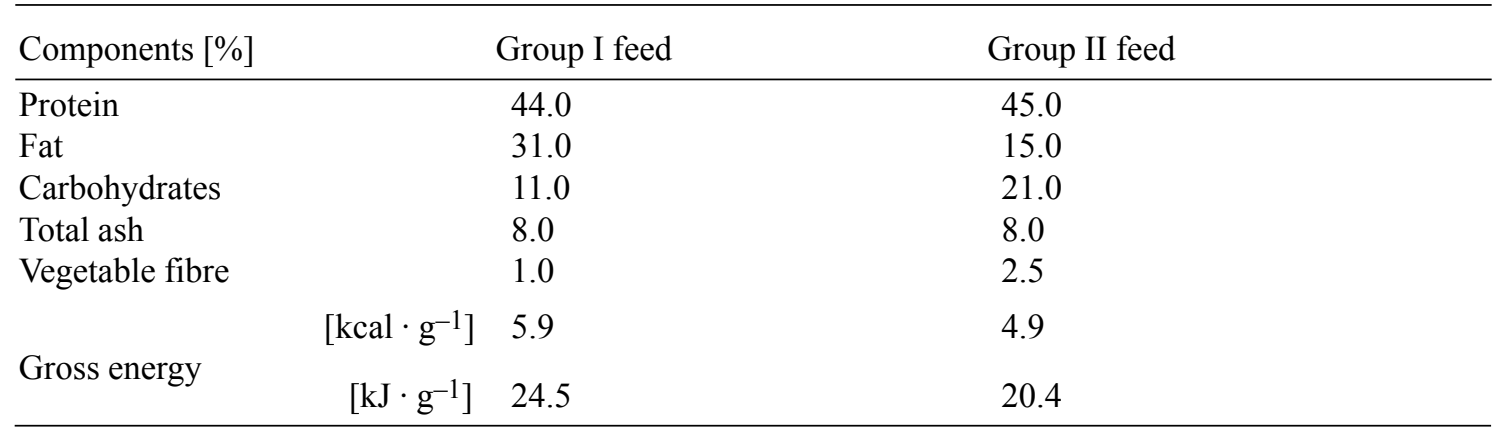


In the fish of both feeding groups, a highly significant $(P \leq 0.01)$ increase in the weight of livers was stated when compared to pre-experiment state, with that being significantly higher in the fish fed high-fat feed.

Also the concentration of lipid peroxidation products increased significantly $(P \leq 0.01)$, being the highest $(P \leq$ $0.01)$ in the fish fed high-fat feed.
However, the content of reduced glutathione decreased significantly $(P \leq 0.01)$, with that being the lowest $(P \leq$ $0.01)$ in the fish of group I.

\section{DISCUSSION}

Environmental factors, such as water temperature, oxygen level, and $\mathrm{pH}$, have a direct effect on fish metabolism

Table 2

Mean unit body weight of carp

\begin{tabular}{lllll}
\hline & Before experiment & $\begin{array}{l}\text { After experiment } \\
\text { Group I } \\
\text { (b) }\end{array}$ & $\begin{array}{l}\text { Group II } \\
\text { (c) }\end{array}$ & Significant differences \\
\hline $\begin{array}{l}\text { Mean unit body weight } \\
{[\mathrm{g}]}\end{array}$ & $170 \pm 10$ & $439 \pm 15$ & $407 \pm 15$ & $\mathrm{a}-\mathrm{b}^{* *}, \mathrm{a}-\mathrm{c}^{* *}, \mathrm{~b}-\mathrm{c}^{* *}$ \\
\hline
\end{tabular}

(b) fed high-fat feed; (c) fed high-carbohydrate feed; ${ }^{*}$ statistically significant difference at $P \leq 0.05$; ${ }^{* *}$ statistically significant difference at $P \leq 0.01 ; \bar{x} \pm s, n=150$

Table 3

Values of selected carp blood components before and after the experiment

\begin{tabular}{|c|c|c|c|c|}
\hline Component & $\begin{array}{l}\text { Before experiment } \\
\text { (a) }\end{array}$ & $\begin{array}{l}\text { After experiment } \\
\text { Group I } \\
\text { (b) }\end{array}$ & $\begin{array}{l}\text { Group II } \\
\text { (c) }\end{array}$ & Significant differences \\
\hline \multicolumn{5}{|l|}{ Protein } \\
\hline$\left[\mathrm{mg} \cdot \mathrm{dL}^{-1}\right]$ & $31.6 \pm 2.6$ & $31.2 \pm 4.1$ & $32.6 \pm 2.2$ & none \\
\hline \multicolumn{5}{|l|}{ Haematocrit } \\
\hline$[\%]$ & $30.33 \pm 2.27$ & $36.50 \pm 2.34$ & $35.67 \pm 3.01$ & $a-b^{* *}, a-c^{*}$ \\
\hline$\left[\mathrm{g} \cdot \mathrm{dL}^{-1}\right)$ & $5.02 \pm 0.49$ & $6.98 \pm 1.17$ & $7.41 \pm 3.01$ & $a-b^{* *}, a-c^{* *}$ \\
\hline \multicolumn{5}{|l|}{ Haemoglobin } \\
\hline$\left[\mathrm{mmol} \cdot \mathrm{L}^{-1}\right]$ & $3.11 \pm 0.30$ & $4.32 \pm 0.72$ & $4.60 \pm 0.54$ & $a-b^{* *}, a-c^{* *}(b)$ \\
\hline
\end{tabular}

(b) fed high-fat feed; (c) fed high-carbohydrate feed; ${ }^{*}$ statistically significant difference at $\mathrm{P} \leq 0.05 ;{ }^{* *}$ statistically significant difference at $P \leq 0.01 ; \bar{x} \pm s, n=36$

Table 4

Content of reduced glutathione (GSH) and concentration of lipid peroxidation products (MDA) in carp livers before- and after the experiment

\begin{tabular}{|c|c|c|c|c|}
\hline Parameters & $\begin{array}{l}\text { Before experiment } \\
\text { (a) }\end{array}$ & $\begin{array}{l}\text { After experiment } \\
\text { Group I } \\
\text { (b) }\end{array}$ & $\begin{array}{l}\text { Group II } \\
\text { (c) }\end{array}$ & Significant differences \\
\hline Weight of livers & $0.62 \pm 0.10$ & $1.34 \pm 0.36$ & $1.05 \pm 0.23$ & $a-b^{* *}, a-c^{* *}$ \\
\hline MDA nmol $\cdot \mathrm{g}^{-1} \cdot$ tissue & $12.99 \pm 1.64$ & $126.66 \pm 28.19$ & $77.78 \pm 16.15$ & $\begin{array}{l}a-b^{* *}, a-c^{* *}, \\
b-c^{*}\end{array}$ \\
\hline GSH nmol $\cdot \mathrm{g}^{-1} \cdot$ tissue & $2366.1 \pm 359.0$ & $1205.5 \pm 317.9$ & $1555.7 \pm 323.1$ & $\begin{array}{l}a-b^{* *}, a-c^{* *}, b-c^{*} \\
b-c^{* *}\end{array}$ \\
\hline
\end{tabular}

(b) fed high-fat feed; (c) fed high-carbohydrate feed; * statistically significant difference at $P \leq 0.05$; ${ }^{* *}$ statistically significant difference at $P \leq 0.01 ; \bar{x} \pm s, n=36$ 
and their health state, and the same on rearing efficiency. The analyses of the physico-chemical conditions of postcooling water, carried out during the whole experiment, permit the concussion that all analysed water parameters were within the ranges suitable for carp (Jaunacey 1982), which was evidenced indirectly by the high body weight gains.

The control weighing revealed intensive body weight gains of fish representing both feeding groups. The increments, however, were significantly higher in fish of group I, fed high fat feed, which, could have been expected considering high energy value of this type of feed. Nevertheless, relatively large gains of body weight in the fish of group II fed high-carbohydrate feed may constitutes an evidence that carp is also able to digest and assimilate excessive amounts of carbohydrates (Wilson 1994, Keshavanath et al. 2002).

Significant increase of haemoglobin $(\mathrm{Hb})$ and haematocrit (Ht) value was observed in the blood of fish of both feeding groups, which undoubtedly resulted from intensive consuption of extruded feeds of increased levels of lipids or carbohydrates. The effect of the feed composition on the blood parameters was also observed by Sobecka (1986). She found an increase of Hb- and Ht levels in carp fed high-protein feeds. On the other hand, Hilge (1978), examining the effect of feed composition on specific blood parameters in carp fry, noticed an increase in $\mathrm{Ht}$ value in the fish fed high-protein- but also high-fat diets. Also Klinger et al. (1996) observed the effect of lipids and their different types in fish diets on the levels of $\mathrm{Ht}$, red blood cells (RBC) and white blood cells (WBC). Lihačeva et al. (2000), however, observed also the effect of not only feed composition but also the feed ration size on $\mathrm{Hb}$ concentration.

A different conclusion reached Serpunin et al. (2002) who was not able to observe any effect of the feeding method on fish blood parameters (total protein, $\mathrm{Hb}, \mathrm{MHC}$, $\mathrm{RBC}, \mathrm{WBC}$ ).

On the other hand, Sobecka (1985) noticed that $\mathrm{Hb}$ level in the blood of carp may depend on physico-chemical conditions of the water. The $\mathrm{Hb}$ concentration increases along with the increase of water temperature, which undoubtedly results from the organism's adaptation to changing environmental conditions.

In the presently reported experiment, no significant changes were observed in the concentration of total protein in the blood serum of carp, either between the feeding groups or in relation to pre-experiment situation. Nevertheless, these concentrations were characteristic both for the season in which the experiment was carried out and for the age of fish (Stosik 1996, Szerow et al. 1996).

The increased level of lipid oxidation products (MDA) and the decreased concentration of reduced glutathione (GSH) in the liver tissue may be indicators of disturbances of organism functioning, resulting from organism proand anti-oxidation unbalance with the predominance of pro-oxidation state, i.e. oxygen stress. It was demonstrated in many studies that oxygen stress is a very important mechanism in the pathophysiology of a number of diseases. Numerous authors point to the influence of environmental conditions and feeding method on fish anti-oxidation status. Hai et al. (1997) showed an increase in the activity of anti-oxidation enzymes and oxidation processes in the tissue homogenates of carp and catfish fed organophosphorus compounds. Gul et al. (2004) observed an increase in the activity of catalase (CAT), superoxide dismutase (SOD), and lipid oxidation products (MDA) concentration in the livers of fish from the areas with high water pollution levels. Enhanced oxidation processes occur also in fish under the influence of heavy metals (Romeo and Gnassia-Barelli 1997, Žikić et al. 2001) as well as during malnutrition and limited access to feed (Pascual et al. 2003).

On the other hand, physiologically higher concentration of antioxidants, both enzymatic and non-enzymatic ones, can be found in Antarctic fishes as an expression of adaptation to constant low temperatures and high oxygen concentration (Ansaldo et al. 2000).

The values of lipid oxidation products (MDA) and reduced glutathione (GSH) concentrations in the fish livers, observed during the experiment, indicate an enhanced oxidation processes in animal organisms of both feeding groups caused by intensive feeding with extruded feeds. At the same time, they suggest that oxidation processes were more intense in the fish of group I, fed high-fat feed.

In this group of fish, larger livers weights were also observed, which could be related to larger gains of unit weight in fish fed high-fat feeds.

It can be concluded that carp utilised high-fat feed slightly better for unit body weight gains. However, it should be emphasised that apart from high body weight gains it is also important to know that fish in the final stage of rearing are a food product which should meet specific nutritive requirements, expressed by its chemical composition. This is particularly related to the content of protein and body lipids of specified quality and nutritive value, which are particularly targeted by perioxidation.

\section{RECAPITULATION}

In modern intensive fish rearing it should be stipulated that production environment would serve natural needs and well-being of cultured fish and would not surpass physiological abilities of their organism; this is also valid for the fact that fish in the final stage of rearing should be a high-value food product for humans, both in respect of specific gustatory qualities and nutritive values.

\section{REFERENCES}

Ansaldo M., Luquet C.M., Evelson P.A., Polo J.M., Llesuy S. 2000. Antioxidant levels from different Antarctic fish caught around South Georgia Island and Shag Rocks. Polar Biology 23: $160-165$.

Arts M.T., Ackman R.G., Holub B.J. 2001. "Essential fatty acids" in aquatic ecosystems: a crucial link between diet and human health and evolution. Canadian Journal of Fisheries and Aquatic Sciences 58: 122-137. 
Budzyńska-Topolowska J., Ziemlański Ś. 1993. Rola wielonienasyconych kwasów tłuszczowych z rodziny n-3 w zapobieganiu i leczeniu miażdżycy. [The role of $n-3$ polyunsaturated fatty acids in prevention and treatment of atherosclerosis.] Czynniki Ryzyka 2: 55-63. [In Polish.]

Gul S., Belge-Kurutas E., Yildiz E., Sahan A., Doran F. 2004 Pollution correlated modifications of liver antioxidant systems and histopathology of fish (Cyprinidae) living in Seyhan Dam Lake, Turkey. Environment International 30: 605-609.

Hai D.Q, Varga S.I., Matcovics B. 1997. Organophosphate effects on antioxidant system of carp (Cyprinus carpio) and catfish (Ictalurus nebulosus). Comparative Biochemistry and Physiology C 117 (1): 83-88.

Hilge W. 1979. The influence of different dietary protein and fat levels on some blood parameters in young mirror carp $(C y$ prinus carpio L.). Proceedings of the World Symposium on Finfish. Nutrition and Fish Feed Technology 2: 173-178.

Jauncey K. 1982. Carp (Cyprinus carpio L.) nutrition-a review. Pp. 216-263. In: Muir J.F., Ronerts R.J. (eds.) Recent advances in aquaculture. Gromm Helm Ltd., London.

Keshavanath P., Manjappa K., Gangadhara B. 2002. Evaluation of carbohydrate rich diets through common carp culture in manured tanks. Aquaculture Nutrition 8: 169-174.

Klinger R.C., Blazer V.S., Echevarria C. 1996. Effects of dietary lipid on the hematology of channel catfish, Ictalurus punctatus. Aquaculture 147: 225-233.

Kolanowski W., Świderski F. 1997. Wielonienasycone kwasy thuszczowe z grupy n-3 (n-3 PUFA). Korzystne działanie zdrowotne, zalecenia spożycia, wzbogacanie żywności. [n-3 polyunsaturated fatty acids ( $\mathrm{n}-3$ PUFA). Beneficial health role, consumption recommendations, and food enrichment.] Żywienie Człowieka i Metabolizm 2: 49-63. [In Polish.]

Lihačeva O.A., Serpunin G.G., Trzebiatowski R., Sadowski J., Odebralska D., 2000. Hematologiczna charakterystyka jesiotra syberyjskiego (Acipenser baeri Brandt, 1869) chowanego w wodzie pochłodniczej przy różnym poziomie żywienia. [Haematological characteristics of Siberian sturgeon (Acipenser baeri Brandt, 1869), reared in post-cooling water, with different feeding regimes.] Folia Universitatis Agriculturae Stetinensis, Piscaria 27 (214): 147-152.

Pascual P., Pedrajas J.R., Toribio F., Lopez-Barea J., Peinado J. 2003. Effect of food deprivation on oxidative stress biomarkers in fish (Sparus aurata). Chemico-Biological Interactions 145: 191-199.

Romeo M., Gnassia-Barelli M. 1997. Effect of heavy metals on lipid peroxidation in the Mediterranean clam Ruditapes decussatus. Comparative Biochemistry and Physiology $\mathbf{C}$ 118: 33-37.

Sadowski J. 1998. Wpływ żywienia ryb metabolicznymi dawkami pasz na wybrane wskaźniki ich chowu w wodzie pochłodniczej. [The effect of feeding fish with metabolic rates of feed on the selected rearing parameters under the conditions of post-cooling water.] PhD Thesis, Agricultural University of Szczecin, Poland. [In Polish.]
Serpunin G.G., Likhatchyova O.A., Trzebiatowski R., Sadowski J., Odebralska D. 2002. Blood parameters of carp (Cyprinus carpio L.) kept in heated water culture at different feeding regimes. Acta Scientiarum Polonorum, Piscaria 1(2): 121-128.

Sobecka E. 1985. Wpływ podwyższonej temperatury wody na wybrane parametry krwi obwodowej karpia (Cyprinus carpio L.). [The effect of increased temperature on selected parameters of peripheral blood of carp (Cyprinus carpio L.).] Zeszyty Naukowe Akademii Rolniczej w Szczecinie, Rybactwo Morskie i Technologia Żywności (113/15): 3-11. [In Polish.]

Sobecka E. 1986. Wpływ poziomu białka w paszy na wybrane parametry krwi obwodowej karpia (Cyprinus carpio L.). [The effect of the protein levels in feed on selected parameters of peripheral blood of carp (Cyprinus carpio L.).] Zeszyty Naukowe Akademii Rolniczej w Szczecinie, Rybactwo Morskie i Technologia Żywności (121/16): 3-10. [In Polish.]

Steffens W., Wirth M. 2005. Freshwater fish-an important source of n-3 polyunsaturated fatty acids: a review. Archives of Polish Fisheries 13: 5-16.

Stosik M. 1996. Poziom globulin i białka całkowitego w surowicy zdrowych krwi (Cyprinus carpio L.). [The level of globulins and total protein in serum of healthy carp (Cyprinus carpio L.)]. Medycyna Weterynaryjna 52 (5): 306-308. [In Polish.]

Szerow D., Niemczuk W., Nawrocka E. 1996. Poziom elektrolitów, białka całkowitego i jego frakcji w surowicy oraz skład morfologiczny krwi karpi stawowych z uwzględnieniem wieku i pory roku. [The content of electrolytes, total protein, and protein fractions in the blood serum and morphotic composition of blood of pond-reared carp, depending on age and season.] Komunikaty Rybackie 4: 15-18. [In Polish.]

Wilson R.P. 1994. Utilization of dietary carbohydrate by fish. Aquaculture 124: 67-80.

Ziemlański Ś., 1997. Tłuszcze w żywieniu człowieka. [Lipds in human nutrition.] Żywienie Człowieka i Metabolizm 2: 35-49. [In Polish.]

Ziemlański Ś., Budzyńska-Topolowska J. 1992. Współczesne poglądy na rolę fizjologiczną wielonienasyconych kwasów thuszczowych z rodziny $n-3$. [Current views on the physiological role of n-3 polyunsaturated fatty acids.] Żywienie Człowieka i Metabolizm 1: 41-47. [In Polish.]

Žikić R.V., Štajn A.Š., Pavlović S.Z., Ognjanović B.I., Saićić Z.S., 2001. Activities of superoxide dismutase and catalase in erythrocytes and plasma transaminases of goldfish $(\mathrm{Ca}$ rassius auratus gibelio Bloch.) exposed to cadmium. Physiological Research 50: 105-111.

Received: 23 March 2005 Accepted: 7 May 2006 